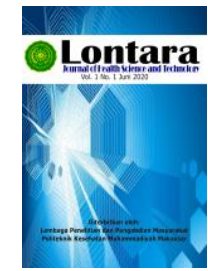

Lontara

Journal of Health Science and Technology

http://jurnal.poltekkesmu.online/lontarariset

Vol 1, No. 2, December 2020, pp 58-64

p-ISSN:0000-0000 dan e-ISSN: 2721-6179

DOI: https://doi.org/

\title{
Gambaran Perbedaan Kadar Timah (Sn) pada Air Buah dan Buah Dalam Kemasan Kaleng
}

\author{
Rahmawati, Muh. Rifo Rianto, Effendy Rasiyanto, Hasrianti \\ Teknologi Laboratorium Medis, Politeknik Kesehatan Muhammadiyah Makassar \\ Email: rahmawatiamma60@gmail.com
}

\begin{tabular}{l}
\hline \multicolumn{1}{c}{ Artikel info } \\
\hline Artikel history: \\
Received;03-10-2020 \\
Revised:20-11-2020 \\
Accepted;07-12-2020
\end{tabular}

\section{Keyword:}

Fruits; Tin Packaging;

Tin Sn; SSA (Atomic

Absorption

Spectrophotometer.

\section{Kata Kunci:}

Buah; Kemasan Kaleng Timah (Sn); SSA (Spektrofotometer Serapan Atom)
Abstract. Canned fruit is fruit that is packaged in packaging, using cans through many processes, aiming to maintain the durability of the packaged fruit. The packaging uses cans made of several heavy metals, one of which is tin (Sn). The process of preserving fruit, which goes through many stages, may allow the heavy metal to be hydrolyzed, causing the canned fruit to contain heavy metals which can be harmful to human health. This study aims to determine and determine the description of differences in tin (Sn) content in fruit water and canned fruit. The type of research used is laboratory observation with simple random sampling technique. Based on the results of research from 5 samples of canned fruit, the results obtained were the results of research on sample A (fruit) $3.19 \mathrm{mg} / \mathrm{kg}$ (water) $2.18 \mathrm{mg} / \mathrm{L}, B$ (fruit) $5.08 \mathrm{mg} / \mathrm{kg}$ (water) $0.49 \mathrm{mg} / \mathrm{L}, C$ (fruit) $1.08 \mathrm{mg} / \mathrm{kg}$ (water) $0.74 \mathrm{mg} / \mathrm{L}, \mathrm{D}$ (fruit) $1.28 \mathrm{mg} / \mathrm{kg}$ (water) $1.56 \mathrm{mg} / \mathrm{L}, \mathrm{E}$ (fruit) $2.92 \mathrm{mg} / \mathrm{kg}$ (water) $2.78 \mathrm{mg} / \mathrm{L}$ ). This research can be concluded that of the 5 samples studied contained levels of lead (Sn) below the maximum threshold for food contamination set by BPOM in 2009, namely $250 \mathrm{mg} / \mathrm{kg}$ so it is still safe for consumption, and the levels of lead (Sn) obtained at fruit is higher than the tin content in fruit water in cans.

Abstrak. Buah kaleng merupakan buah yang dikemas dalam kemasan, menggunakan kaleng melewati banyak proses, bertujuan untuk mempertahankan keawetan dari buah yang dikemas. Pada pengemasan menggunakan kaleng terbuat dari beberapa logam berat salah satunya seperti timah ( $\mathrm{Sn})$. Proses pengawetan pada buah yang melewati banyak tahap dapat saja memungkinkan logam berat tersebut terhidrolisis sehingga menyebabkan buah kemasan kaleng mengandung logam berat yang dapat membahayakan bagi kesehatan manusia. Penelitian ini bertujuan untuk menentukan dan menegetahui gambaran perbedaan kadar timah ( $\mathrm{Sn}$ ) pada air buah dan buah kemasan kaleng. .Jenis penelitian yang digunakan bersifat observasi laboratorik dengan teknik pengambilan sampel simple random sampling. Berdasarkan hasil penelitian dari 5 sampel buah kaleng diperoleh hasil penelitian pada sampel A (buah) 3.19 $\mathrm{mg} / \mathrm{kg}$ (air) $2.18 \mathrm{mg} / \mathrm{L}, \mathrm{B}$ (buah) $5.08 \mathrm{mg} / \mathrm{kg}$ (Air) $0.49 \mathrm{mg} / \mathrm{L}$, C (Buah) $1.08 \mathrm{mg} / \mathrm{kg}$ (air) $0.74 \mathrm{mg} / \mathrm{L}, \mathrm{D}$ (buah) $1.28 \mathrm{mg} / \mathrm{kg}$ 
(air) $1.56 \mathrm{mg} / \mathrm{L}$, E (buah) $2.92 \mathrm{mg} / \mathrm{kg}$ (air) $2.78 \mathrm{mg} / \mathrm{L}$ ). Penelitian ini dapat disimpulkan bahwa dari 5 sampel yang diteliti mengandung kadar timah ( $\mathrm{Sn}$ ) di bawah ambang batas maksimum cemaran makanan yang ditetapkan oleh BPOM pada tahun 2009 , yaitu $250 \mathrm{mg} / \mathrm{kg}$ sehingga aman dikonsumsi dan kadar timah (Sn) yang diperoleh pada buah lebih tinggi dibandingkan dengan kadar timah pada air buah dalam kemasan kaleng.

\section{Coresponden author:}

Email: rahmawatiamma60@gmail.com

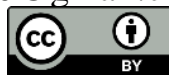

artikel dengan akses terbuka dibawah lisensi CC BY -4.0

\section{PENDAHULUAN}

Pada zaman modern ini, proses pengemasan buah yang dikemas dalam kaleng telah menjadi pilihan makanan yang cukup digemari oleh masyarakat Indonesia. Buah kemasan kaleng banyak digemari karena praktis, mudah didapatkan dipasar tradisional maupun modern (swalayan), tahan lama dan tidak mudah busuk. Meskipun kemasan kaleng memberikan banyak keuntungan dalam pengemasan makanan, namun keamanan dan pengaruhnya terhadap makanan tetap harus diperhatikan. Komponen logam pada kemasan kaleng dapat berimigrasi ke dalam produk makanan yang dikemas. Migrasi tersebut dapat menimbulkan kontaminasi logam pada produk makanan.

Pada proses pengemasan produk pangan, bagian dalam kaleng (sebagaimana halnya bagian luar kaleng) harus bersifat tahan korosi. Untuk menghindari hal tersebut, biasanya pelat baja dilapisi dengan timah. Timah digunakan karena kuat dan daya tahannya yang baik terhadap korosi. Bila lapisan timah ini terkelupas atau larut ke dalam produk yang dikemasnya, maka logam-logam yang terdapat pada lapisan baja didalamnya dapat lepas dan mengontaminasi produk makanan.

Buah yang dikemas dalam kaleng dapat terkontaminasi logam berat yang berasal dari bahan penyusun kaleng, terutama apabila kemasan kaleng tersebut sudah berkarat atau lapisan timahnya sudah terkelupas atau rusak. Selain buah, juga terdapat air buah yang dapat terkontaminasi dengan logam-logam berat pada kemasan kaleng. Beberapa logam berat yang dapat mengkontaminasi produk kalengan seperti timah $(\mathrm{Sn})$. Timah $(\mathrm{Sn})$ pada tinplate dapat larut ke dalam produk yang dikemasnya dan mencemari produk tersebut. Buah dan air buah yang dikemas dalam kaleng dapat terkontaminasi logam berat yang berasal dari bahan penyusun kaleng, terutama apabila kemasan kaleng tersebut sudah berkarat atau lapisan timahnya sudah terkelupas atau rusak. (Adams, 2010)

Kontaminasi logam berat timah dalam makanan dengan konsentrasi yang cukup tinggi dapat menimbulkan efek buruk terhadap kesehatan manusia. Logam-logam berat akan berbahaya jika masuk dalam sistem metabolisme tubuh dengan jumlah yang melebihi ambang batas. Toksisitas akut dari logam-logam berat umumnya menimbulkan gangguan saluran pencernaan seperti perut kaku, mual, 
muntah, dan diare, terutama pada anak-anak.

Makanan sangat penting bagi manusia karena salah satu kebutuhan pokok untuk kelangsungan hidupnya. Untuk itu makanan yang dikonsumsi manusia selain harus terpenuhi kebutuhan gizinya, juga harus terjamin tidak boleh sampai menimbulkan hal-hal yang tidak diinginkan seperti keracunan bahan tambahan makanan yang ditamabahkan makanan.

Masalah keracunan makanan hampir setiap tahun selalu ada dan angka kejadiannya cukup tinggi. Sumber terbesar keracunan makanan yang terjadi di Indonesia berada pada usaha jasa boga atau katering untuk karyawan maupun jajanan anak sekolah.

Badan Pengawas Obat dan Makanan (BPOM) menetapkan persyaratan batas maksimum cemaran logam pada bahan pangan demi menjamin keamanan produk makanan. Batas cemaran logam timah (Sn) pada produk pangan yang diolah dengan proses panas dan dikemas dalam kaleng adalah $250 \mathrm{mg} / \mathrm{kg}$. BPOM (2009).

Menurut penelitian yang telah dilakukan oleh Vera (2011), menunjukkan hasil bahwa buah kaleng yang dikemas dalam kemasan dapat terkontaminasi logam berat yang berasal dari komponen kaleng. Kontaminasi logam berat tersebut akan berbahaya bila masuk dalam metabolisme tubuh dalam jumlah melebihi ambang batas yang diizinkan. Hasil penelitian yang dilakukan menunjukkan bahwa buah lengkeng kemasan kaleng yang memiliki masa simpan yang baru (masa simpan kurang dari 1 tahun) mengandung timah dengan kadar yang lebih rendah bila dibandingkan dengan buah lengkeng kemasan kaleng yang masa simpan sedang (antara 1 hingga 2 tahun) (Perdana, 2019).

Berdasarkan resiko pencemaran buah kaleng oleh logam berat timah yang dapat membahayakan kesehatan masyarakat, maka perlu dilakukan pemeriksaan lebih lanjut terhadap kontaminasi logam tersebut pada buah kemasan kaleng yang terdapat di pasaran. Analisis cemaran logam dalam sampel buah lengkeng dapat dilakukan dengan menggunakan suatu metode analisis kuantitatif yang mampu menetapkan kadar unsur-unsur logam dalam jumlah kecil. Metode yang sesuai yaitu Spektrofotometri Serapan Atom (SSA) karena mempunyai kepekaan yang tinggi, selektif untuk penetapan kadar logam, pelaksanaan yang relatif sederhana, dan interferensinya sedikit. Blunden, S., \& Wallace, T. (2003).

Berdasarkan uraian diatas, maka tujuan dari penelitian ini adalah untuk menentukan kadar timah (Sn) yang terdapat dalam air buah dan buah kemasan kaleng, serta untuk mengetahui gambaran perbedaan kadar imah (Sn) yang terdapat dalam air buah dan buah dalam kemasan kaleng.

\section{METODE}

Jenis penelitian yang digunakan adalah observasi laboratorik yang bersifat deskriptif yang dilaksanakan di Laboratorium Kimia Kesehatan BBLK (Balai Besar Laboratorium Kesehatan) Kota Makassar.

Populasi yang digunakan dalam penelitian ini adalah semua jenis buah kemasan kaleng, dan sampel yang digunakan dalam penelitian ini adalah beberapa buah kaleng dengan merek yang berbeda 
sebanyak 5 buah kaleng.

Teknik pengambilan sampel dalam penelitian ini adalah simple random sampling (acak), yaitu sistem acak sederhana.

\section{HASIL DAN PEMBAHASAN}

\section{A. HASIL PENELITIAN}

Penelitian ini dilakukan untuk menentukan kadar cemaran logam timah dalam air dan buah kemasan kaleng dengan merek yang berbeda. Berdasarkan hasil yang diperoleh, ditentukan kelayakan buah kemasan kaleng tersebut untuk dikonsumsi oleh masyarakat. Kelayakan dapat diketahui dengan melihat ambang batas maksimum cemaran logam berat dalam makanan yang telah ditetapkan oleh Badan Pengawas Obat dan Makanan (BPOM).

Berdasarkan hasil penelitian yang telah dilakukan di Balai Besar Laboratorium Kesehatan Makassar (BBLK) untuk penetapan kadar timah (Sn) dalam air dan buah kemasan kaleng dengan menggunakan Spektrofotometer Serapan Atom (SSA) diperoleh hasil pemeriksaan pada tabel 1, sebagai berikut:

Tabel 1. Hasil Pemeriksaan Larutan Standar Timah (Sn)

\begin{tabular}{ccc}
\hline Sampel ID & Konsentrasi $(\mu \mathrm{g} / \mathrm{dL})$ & Absorbansi \\
\hline 1 & 0,0000 & 0,0021 \\
\hline 2 & 10,0000 & 0,0070 \\
\hline 3 & 20,0000 & 0,0144
\end{tabular}

Sumber: Data Primer, 2019

Pada tabel 1 menunjukkan bahwa besar absorbansi pada berbagai konsentrasi larutan standar yang dibuat dan akan digunakan untuk pembuatan deret kurva kalibrasi. Dengan menggunakan data tersebut dapat dibuat kurva kalibrasi standar Timah (Sn) untuk mengetahui adanya hubungan linear antara konsentrasi yang diukur dengan absorbansi yang dihasilkan.

Sampel yang digunakan dalam penelitian ini adalah beberapa jenis buah kemasan kaleng dengan merek yang berbeda dan dibeli di swalayan Kota Makassar. Hasil penelitian untuk pemeriksaan kadar timah ( $\mathrm{Sn}$ ) dapat dilihat pada tabel 2, sebagai berikut:

Tabel 2. Hasil Pemeriksaan Konsentrasi dan Kadar Timah (Sn) dalam Sampel

\begin{tabular}{|c|c|c|c|c|c|c|c|}
\hline \multirow{2}{*}{ No } & \multirow{2}{*}{ Sampel } & \multirow{2}{*}{ Absorbansi } & \multirow{2}{*}{$\begin{array}{c}\text { Konsentrasi } \\
\mu \mathrm{g} / \mathrm{L}\end{array}$} & \multicolumn{2}{|c|}{ Kadar } & \multicolumn{2}{|c|}{ Kadar } \\
\hline & & & & $\mu \mathrm{g} / \mathrm{g}$ & $\mu \mathrm{g} / \mathrm{mL}$ & $\mathrm{mg} / \mathrm{kg}$ & $\mathrm{mg} / \mathrm{L}$ \\
\hline 1 & A (buah) & 0,4113 & 652,4523 & 3,19 & & 3,19 & \\
\hline 2 & B (buah) & 0,3884 & 615,9874 & 5,09 & & 5,09 & \\
\hline 3 & $\mathrm{C}$ (buah) & 0,1534 & 241,7835 & 1,08 & & 1,08 & \\
\hline 4 & D (buah) & 0,1747 & 275,7007 & 1,28 & & 1,28 & \\
\hline 5 & E (buah) & 0,3753 & 595,1274 & 2,92 & & 2,92 & \\
\hline 6 & A (air) & 0,1400 & 220,4459 & & 2,18 & & 2,18 \\
\hline 7 & B (air) & 0,0340 & 51,6561 & & 0,49 & & 0,49 \\
\hline 8 & $\mathrm{C}$ (air) & 0,0498 & 76,4968 & & 0,74 & & 0,74 \\
\hline 9 & $\mathrm{D}$ (air) & 0,1011 & 158,5032 & & 1,56 & & 1,56 \\
\hline 10 & E (air) & 0,1777 & 280,4778 & & 2,78 & & 2,78 \\
\hline
\end{tabular}

Sumber: Data Primer, 2019 
Pada tabel 2 menunjukkan hasil bahwa keseluruhan sampel positif terdapat logam berat timah (Sn) dengan konsentrasi dan kadar yang berbeda-beda.

\section{B. PEMBAHASAN}

Penetapan kadar cemaran logam berat timah (Sn) dalam air dan buah kemasan kaleng ini dilakukan dengan menggunakan spektrofotometer serapan atom. Alat SSA direkomendasikan untuk penetapan logam berat karena memiliki sensitifitas dan sangat spesifik untuk unsur yang akan dianalisis, serta sederhana dalam pengerjaannya, dan menghasilkan presisi yang baik. Blunden, S., \& Wallace, T. (2003).

Pada penelitian ini menggunakan 5 sampel buah kemasan kaleng dengan 2 tipe preparasi sampel yaitu destruksi kering untuk specimen berupa sampel buah kemasan kaleng dan dekstruksi basah untuk sampel air pada buah kaleng. Menurut Raimon (1993) bahwa destruksi bertujuan untuk mengurai bentuk organik dari logam menjadi bentuk logam anorganik. Unsur-unsur logam dalam matriks berikatan dengan komponen lain dalam matriks. Karena dianalisis dengan spektrofotometer serapan atom, maka ikatan tersebut harus diputus untuk mendapatkan unsur logam yang bebas.

Destruksi kering merupakan perombakan organik logam dalam sampel menjadi logam anorganik dengan cara pengabuan sampel dalam furnace dan memerlukan suhu pemanasan tertentu. Umumnya diperlukan suhu $400-800^{\circ} \mathrm{C}$ tapi suhu ini sangat tergantung terhadap jenis sampel yang akan dianalisis. (Dewi, D. C. 2012).

Destruksi basah dengan asam sudah digunakan secara luas untuk penyiapan berbagai macam sampel logam. Metode ini sederhana, cepat, dan relatif murah. Umumnya digunakan asam klorida, asam nitrat, asam perklorat, asam fluorida, dan hidrogen peroksida. Selain itu, dapat pula digunakan campuran asam untuk mendapatkan kondisi oksidasi yang lebih baik.

Masing-masing larutan hasil destruksi air dan buah kemasan kaleng diukur absorbansinya dengan panjang gelombang yang spesifik dan kondisi pengukuran yang optimum untuk logam timah (Sn). Absorbansi hasil pengukuran dimasukkan ke dalam persamaan deret kurva kalibrasi sehingga diperoleh konsentrasi logam dalam satuan $\mu \mathrm{g} / \mathrm{L}$. Konsentrasi yang diperoleh dimasukkan ke dalam rumus perhitungan kadar logan berat timah (Sn) sehingga diperoleh kadar untuk buah kemasan kaleng dalam satuan $\mu \mathrm{g} / \mathrm{g}$ dan kadar untuk air buah kemasan kaleng dalam satuan $\mu \mathrm{g} . \mathrm{mL}$. Kadar tersebut dikonversi ke dalam satuan $\mathrm{mg} / \mathrm{kg}$ sehingga diperoleh kadar logam timah dalam sampel (bobot kering dan bobot basah), sehingga dapat dibandingkan hasilnya dengan kadar ambang batas cemaran logam timah (Sn) yang diizinkan.

Hasil penelitian yang dilakukan menunjukkan bahwa pada pemeriksaan sampel air buah dan buah kemasan kaleng diperoleh kadar timah di bawah ambang batas maksimum cemaran makanan yang ditetapkan oleh BPOM pada tahun 2009, yaitu $250 \mathrm{mg} / \mathrm{kg}$ untuk produk pangan yang diolah dengan proses panas dan dikemas dalam kaleng, sehingga masih aman untuk dikonsumsi. 
Cemaran logam berat timah yang terdapat pada buah dan air pada kemasan kaleng, baik merek A, B, C, D, dan E berasal dari kaleng yang digunakan sebagai wadah. Jenis kaleng yang digunakan untuk mengemas makanan kaleng adalah tinplate yaitu kaleng yang terbuat dari baja dan dilapisi oleh timah putih. Kontaminasi timah $(\mathrm{Sn})$ pada buah dan air buah kemasan kaleng tersebut dapat disebabkan oleh lapisan timah pada bagian dalam kaleng yang larut ke dalam produk. Logam timah yang larut ke dalam produk pangan dipengaruhi oleh lama masa simpan dan kondisi penyimpanan sehingga konsentrasi dalam makanan dapat meningkat apabila kemasan kaleng dibuka atau disimpan dalam waktu yang lama dan dengan suhu yang tinggi. Semakin lama masa simpan, semakin besar waktu kontak wadah dengan makanan sehingga kemungkinan perpindahan timah juga semakin besar. Menurut Laroussen dan Brown (1996) semakin lama masa simpan, semakin lama pula waktu kontak antara buah, air dan wadahnya. Dengan demikian, semakin besar pula kemungkinan logam timah (Sn) dapat diserap oleh buah.

Kadar timah ( $\mathrm{Sn}$ ) yang diperoleh pada buah lebih tinggi dibanding dengan kadar timah pada air buah kemasan kaleng. Adanya perbedaan tersebut dapat disebabkan oleh wujud dari kedua sampel yaitu zat padatan dan zat cairan. Kadar zat padatan lebih tinggi dibanding zat cair dikarenakan zat padatan memiliki pori-pori yang dapat menyerap logam timah $(\mathrm{Sn})$ dan tidak mudah larut sedangkan pada zat cair mudah larut sehingga kadarnya lebih rendah. Padatan memiliki pori-pori kecil sehingga molekul terikat erat satu sama lain dan dapat menciptakan keadaan yang kaku. Setiap atom atau molekul dikurung oleh atom atau melekul tetangganya menyebabkan tidak bisa berpindah, sehingga zat padat memiliki bentuk dan volume tertentu. Sementara dalam cairan, atom-atom atau molekulmolekul tidak terikat erat karena memiliki pori-pori besar, sehingga atom atau molekul dapat bergerak bebas di sekitarnya.

\section{KESIMPULAN}

Berdasarkan hasil penelitian ini disimpulkan bahwa Kadar timah (Sn) yang diperoleh pada 5 smpel buah kemasan kaleng dengan menggunakan alat SSA (spektrofotometer serapan atom) yaitu pada sampel A, B, C, D, dan E masing-masing 3.19; 5.08; 1.08; 1.28; 2.92 mg/kg, sedangkan kadar timah (Sn) pada air buah diperoleh yaitu pada sampel A, B, C, D, dan E masing-masing 2,18; 0.49; 0.74; 1.56; $2.78 \mathrm{mg} / \mathrm{L}$, tidak melebihi ambang batas maksimum yang dizinkan menurut BPOM (2009) sebesar $250 \mathrm{mg} / \mathrm{kg}$. Kadar timah (Sn) yang diperoleh pada buah lebih tinggi dibandingkan dengan kadar timah pada air buah kemasankaleng.

\section{SARAN}

Saran untuk peneliti selanjutnya bahwa perlu dilakukan penelitian lanjutan terhadap perbedaan kadar $(\mathrm{Sn})$ dan $(\mathrm{Pb})$ pada buah kemasan kaleng dan bagi masyarakat sebaiknya lebih mengutamakan untuk mengkonsumsi buah segar. 


\section{UCAPAN TERIMA KASIH}

Terima kasih diucapkan kepada Direktur, Kaprodi D3 TLM yang telah memberikan izin penelitian, dan seluruh civitas akademika prodi TLM Politeknik Kesehatan Muhammadiyah Makassar serta pihak BBLK yang telah membantu terlaksananya seluruh rangkaian penelitian ini.

\section{DAFTAR PUSTAKA}

Adams, I. U., \& Happiness, I. U. (2010). Quantitative specification of potentially toxic metals in expired canned tomatoes found in village markets. Nat. Sci, 8, 54-58.

BPOM, RI. (2009). Penetapan Batas Maksimum Cemaran Mikroba Dan Kimia Dalam Makanan. Peraturan Kepala Badan Pengawas Obat Dan Makanan Republik Indonesia Nomor HK. 00.06, $1,4011$.

Balai Besar Laboratorium Kesehatan, 2018, Instruksi Kerja Metode Pemeriksaan Logam dengan Spektrofotmeter serapan atom, Instalasi Kimia Kesehatan Dan Toksikologi, Makassar.

Blunden, S., \& Wallace, T. (2003). Tin in canned food: a review and understanding of occurrence and effect. Food and Chemical Toxicology, 41(12), 1651-1662.

Dewi, D. C. (2012). Determinasi kadar logam timbal $(\mathrm{Pb})$ dalam makanan kaleng menggunakan destruksi basah dan destruksi kering. Alchemy.

Food Standards Agency. (2002). Tin in canned fruit and vegetables. 30 November 2010. http://www.food.gov.uk/science/surveillance.

Gad, S. C., Anderson, B., Kamrin, M., Hakkinen, P. J., \& Peyster, A. D. (2005). Encyclopedia of toxicology.

Gandjar, I. G., dan Rohman, A. (2007). Kimia Farmasi Analisis. Yogyakarta: Pustaka Belajar.

Godt, J., Scheidig, F., Grosse-Siestrup, C., Esche, V., Brandenburg, P., Reich, A., \& Groneberg, D. A. (2006). The toxicity of cadmium and resulting hazards for human health. Journal of occupational medicine and toxicology, 1(1), 1-6.

Larousse, J., \& Brown, B. E. (Eds.). (1996). Food canning technology. Wiley-VCH.

Perdana, W. W. (2019). Analisis Logam Berat di Kemasan Kaleng. AGROSCIENCE (AGSCI), 9(2), 215-223.

Worsfold, P., Townshend, A., Poole, C. F., \& Miró, M. (2019). Encyclopedia of analytical science. Elsevier.

Yuliana, H. (1995). Pengaruh Bakteri Asam Laktat Terhadap Kandungan Logam Fe, Sn, Dan Zn Pada Ikan Dalam Kaleng Selama Penyimpanan (Doctoral dissertation, Institut Teknologi Sepuluh Nopember). 